\title{
GOD'S INSURMOUNTABLE WILL AND THE MYSTERY OF THE FREEDOM OF CREATED BEINGS. COMMENTS ON THE BOOK OPATRZNOŚĆ BOŻA, WOLNOŚĆ, PRZYPADEK BY DARIUSZ ŁUKASIEWICZ
}

After reading Opatrzność Boża, wolność, przypadek ${ }^{1}$ (Divine Providence, Freedom, Chance) the conclusion we are likely to draw is that the most important problem of all, both philosophical and theological, is the nature of the relationship between the freedom of created beings and the power, knowledge and will of God.

The phrase "created beings" applies primarily to us humans, but its application can be extended to all beings endowed with self-awareness.

The impression that the issue of freedom is of primary importance stems from the fact that for the Author of Divine Providence all the positions discussed in the book are related to the topic of human freedom in one way or another; this is equally true of two varieties of classical theism mentioned in the book-Thomistic and Anselmian theism (so-called Molinism), as well as non-classical theisms-open theism and probabilistic theism.

Probabilistic theism, sometimes called "theology of chance" in the book, is the Author's preferred position. He warns us, however, in the last sentence of the Conclusion that "in philosophy, it is difficult to find any important view that would not raise some kind of resistance or for whose acceptance we would not have to pay a certain 'metaphysical' price" (p. 362).

After reading the entire book, I had to wonder what to say: the hesitation was caused by the wide range of issues raised and discussed on its pages. In the end,

StanisŁaW JUdycki, Prof. Dr Hab., Head of the Department of Metaphysics, Philosophy of Religion and Contemporary Philosophy in the Institute of Philosophy, Sociology and Journalism, University of Gdańsk; address for correspondence: ul. J. Bażyńskiego 4, 80-952 Gdańsk, Poland; e-mail: s.judycki@ug.edu.pl; https://orcid.org/0000-0003-3586-846X.

${ }^{1}$ Dariusz ŁuKaSIEWICZ, Opatrzność Boża, wolność, przypadek. Studium z analitycznej filozofii religii (Poznań: W drodze, 2014). 
I concluded that if it is true that human freedom is so important, then in the commentary I should try to formulate such a solution to the problem of creaturely freedom for which we would need to pay the smallest metaphysical price, or, if possible, no price at all.

In this way, it seems to me, I will be able to do most justice to the vast amount of work that the Author of Divine Providence put into his book, and on the other hand - to advance the discussion on the topic. Whether I succeed within the limits of this commentary the reader will have to judge for himself.

First, however, some general remarks. When, from the perspective of six years, I think about the books published as part of the series Wyktady otwarte z teologii naturalnej im. J. M. Bocheńskiego (J. M. Bocheński Open Lectures on Natural Theology), my impressions are as follows. The first book in the series, my very own Bóg $i$ inne osoby (God and Other Persons), is an overarching speculation rummaging through the domain of theology in a somewhat loose, but also serious way. The second book in the series, Pomazaniec. Przyczynek do chrystologii filozoficznej (The Anointed One. A Contribution to Philosophical Christology) by Marian Grabowski, is an existentially tuned attempt to comprehend the humanity of Jesus. The third work, Spór o istnienie Boga. Analityczno-intuicyjny argument na rzecz teizmu (The Controversy over the Existence of God. An Analytical-Intuitive Argument for Theism) by Jacek Wojtysiak, is an apology, dynamic and quite imaginative, while the fourth book, Życie wieczne. Przyczynek do eschatologii filozoficznej (Eternal Life. A Contribution to Philosophical Eschatology) by Ireneusz Ziemiński, is surrounded by an aura of doubt careful reflection on various possibilities regarding the destiny of human beings.

Seen against this background, Dariusz Łukasiewicz's Divine Providence, seems to be a grand collage made of various attempts to understand who "God is in himself" and who God is in relation to the beings he created. The author presents diverse issues in a very clear way; from the very beginning, the reader feels captivated by the discourse; all ideas are very elegantly worded, and, when necessary, restated; summaries and reminders clarify how to understand what is currently considered as compared to things discussed previously. The book seems to be a very successful presentation of the so-called "eschatological questions." At the same time, the author knows how to keep his distance from such issues: it is this distance that forces us to remember that for every philosophical and theological solution there is a price to be paid, such as, for instance, rejection of certain sets of common sense intuitions about the world and human persons. One of the book's strengths is, certainly, the fact that it takes up issues from the natural sciences: the earlier publications in the J. M. Bocheński lecture series were rather lacking 
in this respect. Topics related to the field of natural sciences, however, did not overshadow the overall metaphysical and systematic approach that characterizes all the considerations offered by the Author of Divine Providence.

The second general topic that I would like to comment on is methodological. Dariusz Łukasiewicz writes that "the goal is to analyze the possibility of reconciliation of the God of Christian theism, whose concept was defined by the Holy Scriptures, the teaching of the Church, and theological thought, with the existence of chance. The existence of chance understood in a specific way is, as it seems, supported by some results offered by the world sciences" (p. 22). Nonetheless, the book proceeds in such a way that its Author does not take up the issue of how one can prove the existence of God, because he only wants as little, or as much, as to figure out whether the idea of the Christian God can be reconciled, on the one hand, with what the natural sciences seem to tell us about the world, and, on the other hand, with the fact that, at least sometimes, we experience ourselves as free thinkers and agents.

Although the Author does not raise the issue of God's existence, the result of his analyses must also have an impact on this problem. Here is how. After reading the book, some readers may end up with the following thought: since it is so difficult to reconcile the idea of God with the idea of human freedom and with the data coming from natural sciences, a suspicion may arise that the concept of the Christian God is so intrinsically incoherent that its referent cannot exist. It is possible, however, to have an opposite impression after reading the entire book, namely that all problems concerning both God and the world are very difficult, but the book clearly shows that when we put theological issues and those related to nature together, we end up dealing with problems that are absolutely crucial, and not just with some kind of outdated subject matter from times long ago of human immaturity and lack of enlightenment. In my own case, after reading the last sentences of Divine Providence, the latter impression prevailed. At the same time, however, I could not agree with probabilistic theism that the Author defends. For this reason, the remainder of this commentary will be devoted to the problem of reconciling human freedom with omniscience, omnipotence, and perfect goodness of Christian God.

Here is how we could formulate the radical dilemma that seems implicit in the concept of freedom that all finite and self-aware creatures are supposed to possess: either it is the case that acts of free will of such beings have causes, and thus cannot be called free, because even pre-philosophical intuition tells us that if something belongs to a certain causal chain, then it cannot be called free action. Or acts of free will have absolutely no causes other than free will itself, whatever 
that is, whether it is some kind of self-propelling force or some miraculous mechanism that functions on its own and cannot be identified with rational or moral or emotional motives, or any other reasons or causes. It would seem that the will can be free in its acts, that is, in different kinds of decisions, only in the latter case.

However, my impression is that free will so understood is something metaphysically impossible; it is some kind of "metaphysical ghost" whose actions cannot be known by God, even though He is, by definition, omniscient. Even worse, those actions would not be known to the owners of such non-causal decision generator, because decisions would come to them "from the outside": the free will mechanism would "reveal" these decisions to them. In fact, we would need to acknowledge that such decisions come from nowhere because they cannot be the result of any cause, or else they would not be free. I am certain that freedom understood in this way does not exist, because it cannot exist; and if it did exist, it would be the most irrational thing in the entire "metaphysical cosmos." I do not even need to add here that no one could be responsible for acts of free will thus understood: neither God nor the "miserable" owners of such a bizarre thing as free will so construed.

If this is the case, we must assume that all our free actions proceed from our individual essence. Then the cause of my decisions is my individual nature or my individual essence. It is I who choose, that is, the I who is my own individual essence; it is not some non-causal decision generator that is attached to me that is doing the choosing. If this second possibility were somehow realized, then everything within the human experience would become completely absurd. According to Christian theism, the individual essence of each one of us was created by God, and, at the time of creation, God knew to the smallest detail how a given person endowed with a specific nature would behave in given circumstances. So, in this respect, there is no chance in the world - in other words, there are no events proceeding from finite self-conscious creatures that would arise due to the non-causal generator commonly known as free will. The world is rational.

If so, then God is not only the creator of these individual creatures, but also the Author of their actions. God not only creates acts of free will, but also sustains them in existence. However, if this is the case, then a simple but devastating objection seems natural: there is no freedom and we are puppets in God's theater. This conclusion, however, seems too hasty, because when we analyze God's relationship with created beings we do not talk about the kind of freedom that I described above, but rather about a certain kind of dialogue whose purpose is education. The dialogue I am writing about here has almost nothing in common with the sad and idyllic image that we can create based on some of Martin Buber's statements, 
where a certain "I" and a certain "thou" who do not want to manipulate each other, look in awe at each other and exchange thoughts. The dialogue between God and created beings is more like ice being crushed by a grand icebreaker where the purpose of this process is to take the core of human beings, which is selfishness, and crush it into dust. Just as the ocean sustains the ice floating in it, so also God sustains and shapes all created beings, including all self-conscious beings, as well as all their acts. We cannot comprehend the boundaries of His power and of the natures sustained in existence by this power, just like we cannot fathom the boundary between ice and the supporting it ocean. We do not deal here, however, with pantheism according to which we would be nothing but "pieces" of some impersonal divine being, for the purpose of "being in the world" is precisely to shape all self-aware created beings into complete independence.

And so, when I have to choose between A and B, when I have a full insight into what A is and what B is, when I am not really forced to choose A or B by motives stemming from my intellect or emotions, then it is still my individual essence which causes me, in such and such circumstances, to choose A or to choose $\mathrm{B}$. The freedom of finite created beings consists, therefore, in acting in accordance with their individual essences, and my conviction that I could choose either A or B is merely the result of the fact that I do not know my individual essence. Freedom, therefore, is ignorance of one's individual nature.

In contemporary framework, this type of position may appear to be a version of so-called compatibilism - a view that in order to be a free being, all you need is freedom of desire, and so I am free when I can want either A or B. As concerns freedom in the libertarian sense, I could be called free only if I am actually able to do either A or B, so the freedom of desire is not enough. This resemblance is, however, superficial because even freedom in the compatibilist sense assumes that I can desire either A or B, and then the question arises of where my acts of volition come from: either they come from the previously described, somehow "attached to me" act generator, or they stem from my individual essence. The first possibility should be rejected, as I have already stated, because it leads to the conclusion that the world is "thoroughly and deeply" irrational. We should acknowledge, therefore, that even my acts of volition come from my individual essence; this essence was created by God, and He knows in every detail how I will behave in specific circumstances.

We would then be dealing with theological determinism, and, consequently, as Dariusz Łukasiewicz often emphasizes, even with philosophical Calvinism. In other words, we would make God responsible for sin. It should be noted at this point that the situation of self-aware creatures is different in the case of natural 
determinism than in the case of theological determinism. When we reflect upon human freedom and reject the existence of a good and holy God who guides the fate of His creatures, then, even if we recognize that we are somehow independent of the world of nature, and therefore free, our situation resembles the situation of a child in the woods in the dark. But if it is a good and holy God who determines our actions by creating individual essences that we are in fact endowed with, then our situation is optimistic, not pessimistic. We are then not some free beings "wandering" around the physical universe, but rather creatures that God looks after. Concerning philosophical Calvinism, which makes God responsible for sin, it all depends on what this sin is supposed to be used for: if it is to lead us to maturity and what is ultimately good for us - eternal life with God, I see no obstacles to accept that God is responsible for sin understood in this way. For ultimately this just means that God is responsible for our eternal happiness.

The interpretation offered so far will be incomplete, however, if we do not mention the purpose of the existence of self-aware creatures in the world. This goal, as I have already mentioned, is dialogue and being molded by God; the dialogue and the molding do not happen, however, in an imaginary way but rather through real and often painful experiences, and also through many situations in which genuine goodness is experienced. I do not know whether to choose A or B; A is attractive to me, B will be unpleasant for me etc., but I feel that I have an obligation to do B; and so I fulfill the obligation, although the fact that I stick to it is not due to some free-act generator which governs my actions, but results from my individual nature that God created, and my awareness of freedom is the awareness of ignorance of this nature. God gives me these experiences so that, through them, he could shape my individual essence in such a way that I could enter eternal life. Without these experiences I would not be who I am meant to be. The goal of these experiences is to overcome selfishness that is inherent in human nature. It is not selfishness in the ordinary sense, however, but rather selfishness understood as the pursuit of self-sufficiency, the pursuit of getting everything for ourselves, enjoying our own uniqueness and the pleasures flowing from what we possess and what we can use. It should be added that not all individual natures that in fact appear in the world need to have experiences of this kind: for instance, perhaps due to their individual natures, children who die at a young age do not need to experience the world to the extent to which many of us need to experience it.

Freedom in the sense of a non-causal free-act generator does not exist. We will experience freedom, true freedom, only in eternal life, and it will become real only when our individual essence is revealed to us. Eternal life, I think, will consist, among other things, in being able to see how all our actions flow from our 
individual essence. ${ }^{2}$ Self-awareness that we currently have is sometimes labeled a "distorting mirror" not just because it does not allow us to see things that will become visible at the time of transition to eternal life, but also because it does not reflect our true and highly individualized nature. We will see our own individual essence simultaneously to seeing our own unique relationship to all objects and people that we have encountered. There seems to be no other general term for naming this experience than "sympathy" or "love," but these words are empty in the sense that they only indicate how we experience our relationship with a particular object or person, each time differently. I understand eternal life of human beings as existence in an infinite time; the experience of time, however, will have a different structure than it does now. In a sense, time will cease to exist because whatever happens - we will always understand the relationship of that event to our individual essence, or towards which we would not have the feeling of sympathy. Nothing will come from the future that we would not immediately love. In this sense, each new phase of the stream of consciousness will consist in discovering what is already known.

The past will also lose its meaning, because nothing of what will be given in our memories will bear the mark of something irretrievably lost: each past event that we remember will bear on itself a sign of the ever-present relationship between our individual essence and past experiences of a particular object or person. And so, although three kinds of temporal "ecstasy" will not stop functioning, everything will be permanently available, and hence it will be constantly present, it will be experienced as happening here and now.

Once we know our relationship to every object and to each person, when we feel sympathy with each object and each person, the need for intimacy will disappear, and will be replaced by a desire to give oneself to others and to have an experience of other people and of the products of their actions. Perfect communion between persons and between persons and the world will require the possibility of experiencing how other people's actions and their creations proceed from their individual essences. It will be an experience similar to a direct observation of the process of creation. The experiences of great artists are nothing but a trace of this experience, because while creating they do not see exactly "how" their creations flow from the unique essences that constitute them.

\footnotetext{
${ }^{2}$ Stanisław JudYcki, Bóg i inne osoby. Próba z zakresu teologii filozoficznej (Poznań: W drodze, 2010); "Kuszenie i wolna wola. O pewnym rozwiązaniu problemu natury relacji między ludzką wolnością a wszechwiedzą Boga," in Filo-sofija 19 (2012/4): 21-36, reprinted in Teologia filozoficzna. Wokót książki Stanisława Judyckiego Bóg i inne osoby, ed. Janusz Pyda (Poznań: W drodze, 2013), 309-30.
} 
The reader of Dariusz Łukasiewicz's book may feel a certain dissatisfaction due to the fact that it does not contain existential considerations, that is, considerations regarding the fate of individual people. Admittedly, such issues are mentioned in the introduction, but only through various citations. Of course, topics of this kind may be of little importance to the speculative gaze of a metaphysician focused on the grandiose faraway objects. Still, the concept of divine providence seems to me to be a "friendly" concept, because those who believe in God's providence seek in it help, support and justification for the fate they experience. At the same time, those who believe in the Christian God do not acknowledge the existence of something like an ancient fate: they do not believe in situations in which forces that are completely indifferent to people's lives make it the case that no matter what a person does, what is meant to happen to him or her, must happen. As I have already mentioned, the relationship between God's actions and our existence remains unknown to us, but at the same time divine omnipotence makes the relationship between earthly events and divine decrees to be very flexible. We can therefore conclude that it makes sense to pray for this or that, even though the prayer will not always be answered as we wish.

However, even if we agree that the relationship between God's omniscience and our fate is, as I called it, "flexible," how does God's providence relate to those countless situations in which one person, for trivial reasons, finds herself in incredible trouble while another person gets bailed out even though the situation seemed to be completely hopeless? How can we reconcile the existence of God's providence with the fact that people whose lives and spiritual "profiles" are completely different, suddenly die in a traffic accident and all they have in common is that they got together on the same plane?

An advocate of probabilistic theism could easily answer that the fact that these people got on the same plane was a coincidence. Their different life paths, resulting from their free decisions, simply crossed on the board of that plane, and God did not know how exactly it was going to happen, that is to say, he knew, but only with certain probability. However, if probable knowledge is not knowledge, but rather only a certain kind of opinion, then it turns out that God did not know who and at what spiritual moment of his or her life would be on board of the plane. I find this solution unconvincing, because I think that God knew exactly why he was guiding their lives in such a way that they got on this plane: given their experiences of the world, he decided that the transition to the "side of eternity" is already for them - at the same time - possible and necessary.

To conclude, let us consider eschatological issues. Supposedly, the freedom that we attribute to ourselves would allow us to decide whether we will be saved 
or condemned. From the point of view of the almighty, perfectly good and holy God, it does not matter whether I choose Malaga or vanilla ice cream in an ice cream parlor, but it does matter whether, because of my own decisions and actions, I am going to do good or evil. However, if the determining factor of salvation and condemnation were to be the non-causal free-act generator that is attached to us in a mysterious way, any eschatological perspective for all created and self-aware beings would become grotesque. If eschatology is not become a game of chance, God must be able to realize his goals. Only then does the concept of divine providence make sense: the kind of providence that speaks to us through what we call random events in our lives.

Through events of this kind God's insurmountable will manifests itself, a will that nothing can overcome, a will that wipes out all human plans, improves upon even the most adverse circumstances and leads to experiences transforming individual human natures. How could it be otherwise? Is it possible to seriously proclaim God's omnipotence and omniscience without acknowledging that $\mathrm{He}$ can do what He wants, while remembering that He wants only the good? And so, there can be no random events, there is only the insurmountable will of God who knows everything and everyone; He does not know them before the act of creation but creates all persons as he wants them to be in eternal life and shapes them by giving them different experiences of "being in the world."

Does it mean that God creates individual conscious beings, whether human or non-human, such that he foreknows at the time of creation that they will be condemned by Him? Perhaps it would be better if we took this responsibility off Him and transferred it to this non-causal free-act generator with which He equips his creatures. God would still be the creator of this generator, but according to probabilistic theism that Dariusz Łukasiewicz supports, God would not know the results of its activity. However, it is immediately evident that God would still end up responsible, for why would $\mathrm{He}$ create some object whose action $\mathrm{He}$ cannot foresee when this action is what determines salvation or damnation? The way out of the problem is as follows.

The necessary and sufficient condition for condemnation is to have the demonic will - hatred of everything that exists. Ultimately, this kind of will must also be directed against itself, and so the demonic will seeks its own destruction. Does God create self-conscious individual beings who, because of their hatred for everything that exists will, in all possible circumstances, strive for nonexistence? I do not think so, because that would contradict His goodness. This does not imply that acts of bad will cannot appear in many created natures, but God's insurmountable will is able to transform these natures so that acts of ill will can, for beings 
of this kind, become the cause of some good. Should we therefore conclude that hell is empty, and that everyone will be saved? This does not have to be the case, because not all empirical persons must be persons in the full sense of the term, and so not all must be able to experience good and evil, or more precisely, to feel the repulsive nature of evil and the goodness of good. Such empirical beings, or empirical persons, would not count as persons in the ultimate metaphysical sense, and they - "at the end of history" - will be condemned, or, to be more precise, the functions that God planned for such beings will be condemned. Therefore, it would be only masks that will be condemned, and never authentic self-aware persons with unique individual natures.

Are we losing something in light of what has been said? Do we need to conclude that there is something wrong with theological determinism? Do we need to label all theories supported by this kind of view as Calvinist? It seems to me that we do not have to pay here any metaphysical price, because everything that exists is like a priceless, one and only, gratuitous gem.

Translated by Justyna Japola and Marcin Iwanicki

\section{BIBLIOGRAPHY}

Grabowski, Marian. Pomazaniec. Przyczynek do chrystologii filozoficznej. Poznań: W drodze, 2011. JUDYCKI, Stanisław. "Kuszenie i wolna wola. O pewnym rozwiązaniu problemu natury relacji między ludzką wolnością a wszechwiedzą Boga." Filo-sofija 19 (2012/14): 21-36.

JUDYCKI, Stanisław. Bóg i inne osoby. Próba z zakresu teologii filozoficznej. Poznań: W drodze, 2010. ŁUKASIEWICZ, Dariusz. Opatrzność Boża, wolność, przypadek. Studium z analitycznej filozofii religii. Poznań: W drodze, 2014.

WoJTYSIAK, Jacek. Spór o istnienie Boga. Analityczno-intuicyjny argument na rzecz teizmu. Poznań:

W drodze, 2012.

ZIEMIŃSKI, Ireneusz. Życie wieczne. Przyczynek do eschatologii filozoficznej. Poznań: W drodze, 2013.

\section{GOD'S INSURMOUNTABLE WILL AND THE MYSTERY OF THE FREEDOM OF CREATED BEINGS: COMMENTS ON THE BOOK OPATRZNOŚĆ BOŻA, WOLNOŚĆ, PRZYPADEK BY DARIUSZ ŁUKASIEWICZ}

$$
\text { Su m m a ry }
$$

This article is a commentary on Opatrzność Boża, wolność, przypadek by Dariusz Łukasiewicz. The main thesis is that freedom in the sense of a non-causal free-act generator does not exist. We will experience freedom, true freedom, only in eternal life, and it will become real only when our 
individual essence is revealed to us. Eternal life will consist, among other things, in being able to see how all our actions flow from our individual essence

Keywords: philosophical theology; free will; determinism; self-knowledge.

\author{
NIEPRZEZWYCIEZŻONA WOLA BOGA I TAJEMNICA WOLNOŚCI \\ STWORZONYCH BYTÓW \\ KOMENTARZ DO KSIĄŻKI OPATRZNOŚĆ BOŻA, WOLNOŚĆ, PRZYPADEK \\ DARIUSZA ŁUKASIEWICZA
}

Streszczenie

Artykuł jest komentarzem do książki Dariusza Łukasiewicza Opatrzność Boża, wolność, przypadek. Zasadniczą jego tezą jest to, że nie istnieje wolność ludzka jako nie-kauzalny generator wolnych aktów. Prawdziwej wolności doświadczymy tylko w życiu wiecznym, a stanie się ona dla nas czymś realnym dopiero wtedy, gdy zostanie nam ujawniona nasza indywidualna istota. Życie wieczne polegać będzie, między innymi, na ujrzeniu, w jaki sposób wszystkie nasze działania wypływają z naszej indywidualnej istoty.

Słowa kluczowe: teologia filozoficzna; wolna wola; determinizm; wiedza o sobie. 